\title{
The Influence of Traditional Culture on College Students' Ideological and Political Education
}

\author{
Li Shi \\ Wuhan Business University,Wuhan,430056, Hubei, China \\ accnushili@163.com
}

Keywords: Traditional Culture, College Student, Ideological and Political Education

\begin{abstract}
For the ideological and political education of college students, Chinese traditional culture is an inexhaustible and important resource. In a certain sense, can college students' ideological and political education truly exert their own advantages? The key link is whether it can absorb nutrition from China's excellent traditional culture, so that it has rich cultural connotation and culture in the construction of its own content. The taste and cultural spirit are consistent with the goal of the entire social and cultural development. The valuable part of Chinese traditional culture has a positive impact on the ideological and political education of college students.
\end{abstract}

\section{Introduction}

Chinese traditional culture has a long history. In the course of historical changes, it has accumulated the most brilliant wisdom of the Chinese nation and the deepest spiritual pursuit. It is the unique social psychology, ethical concept, value orientation, way of thinking, aesthetic taste and other spiritual characteristics of the Chinese nation. Overall characterization. Chinese traditional culture attaches importance to the development of an organic overall consciousness, and believes that things are a whole of close ties, and are good at taking care of parts and parts from the whole and from the overall situation. As early as in the era of human axis proposed by Jaspers, Chinese pre-Qin thinkers began to think more about the relationship between people. Chinese traditional culture places great emphasis on the study of life. It believes that life is a whole, a whole that is closely connected with others, with groups, and with the heavens and the earth. People are only part of it. Emphasize that people can break through the various external forms of physical and mental restraint through deep thinking and inner Ming, and admire the self-cultivation and life-long inner sanctification. They hope to have the ideal personality of the hero and the husband, and realize the inner transcendence and freedom of their own spirit; At the same time, it also emphasizes the political ideal of "outside the king", that is, the Qi family ruled the country and the world, and the positive attitude towards life, and finally reached the realm of unity with the heart, unity with heaven, and unity with the Tao. This kind of holistic thinking, the inner world, the heavens and the human beings, the world outlook, the outlook on life and the spiritual feelings are precisely the important core of Chinese traditional culture. They are also the internal driving force for the continuous advancement of the Chinese nation and the uninterrupted Chinese civilization.

One is a day. Chinese traditional culture has the basic concept of "Heaven and Man are one". He believes that heaven is the object of all things, and it is the "rationality" of all people and things. This "natural reason" is both transcendence and embedding in everything, so everything is in everything. It is the same root of the same root. "I am one of the things, and there is no distinction between the inside and the outside." Heaven is both the fundamental and the ideal of human beings. Everything is done by people, law, heaven, heaven, and nature. Law as a natural quasi-balance, do not have to separate me from me and non-self, and eliminate the contradiction between inside and outside. The unity of heaven and man is one with the Tao, one with the same, and one with the body. Therefore, Chinese traditional culture can propose valuable propositions that live in harmony with nature. The purpose of Western culture to understand nature is to transform nature, and to advocate and understand the externality in the way of "self-contained things" and "class-like", emphasizing 
the ultimate challenge to physical fitness and treating nature with the attitude of conquerors. The traditional Chinese culture advocates that it can blend with the heavens and the earth from the inside out. It can be known to all things. It can be discerned, and it can be considered infinitely. It does not distinguish between the subject and the guest, emphasizes the homology of all things, and everything is the same. Studying the universe is the study of the heart. Is to study yourself.

The second is the same truth. Chinese traditional culture believes that "truth is the best, truth is the pursuit of good, truth is the principle of perfection." And the improvement of moral spirit is the first orientation of life value, to a large extent, traditional Chinese culture Paying attention to life wisdom is greater than asking for specific objective knowledge, instead focusing on and improving internal cultivation, life is internalized into heart and spirit, and believes that things can be known, things can be practiced, as long as they strengthen self-cultivation, they can With heart and spirituality, you can know everything. It does not advocate the attitude of seeking knowledge for seeking knowledge, and agrees that "to know that knowledge is inseparable from the fellow practitioners, that the true knowledge of the universe and the goodness of life are two sides of one thing", "the poor is the best," and "the reverence is the knowledge." Therefore, traditional culture emphasizes that "things other than language awareness need to be carefully thought and sent to understand", but can only be understood, can not be said, and ultimately "to hear the news, the death of the night can be awkward", and this is not just the universe. The fundamental Dafa is also the principle of perfection in life. Seeking truth is seeking good.

\section{The Value of Chinese Traditional Culture in College Students' Ideological and Political Education}

Today's ideological and political education of college students needs constant innovation, constantly exploring full and effective educational resources, and the profound Chinese traditional culture is undoubtedly a huge treasure house. General Secretary Xi Jinping emphasized: "Cultivating and promoting the core values of socialism must be based on the fine traditional Chinese culture. The profound and profound Chinese traditional culture is the foundation for us to gain a foothold in the world cultural agitation. Ideas and ethics must adhere to the past, use the past, introduce new ideas, treat them in a differentiated way, inherit them with sublation, and strive to use the cultural wealth created by the Chinese nation to educate people and educate people." Chinese traditional culture is the ideological fertile ground for ideological and political education of college students. The ideological and political education of Chinese college students has its guiding ideology of the times, but it is inseparable from the ideological soil of Chinese traditional culture, excavating the ideological and moral resources in Chinese traditional culture, and guiding the students of today's colleges to use the overall vision and thinking with the excellent traditional culture as the carrier. Go to the problem, get out of the professional barriers, and more comprehensively and connect to give yourself a general charge, and stimulate students to learn and explore more widely, instead of just focusing on their own disciplines and majors, big and empty, small and narrow. , are not enough. At the same time, it emphasizes the improvement of the heart, truly realizes the common relationship between seeking truth and seeking truth, and knowing and repairing, reassessing its own value and correctly positioning itself, establishing a scientific world outlook, outlook on life and values, not in the process of seeking knowledge and seeking knowledge. Forgetting the heart and respecting the virtues is conducive to realizing the all-round development of people.

Chinese traditional culture is the spiritual lifeline of college students' ideological and political education. Chinese traditional culture can be passed down today, and it is endless with its "creative spirit of human culture, the dialectical spirit of the combination of rigidity and softness, the spirit of exploration of the heavens, the humanistic spirit of virtue and morality, and the different spirits of communication. The spirit of public responsibility is inseparable. These spirits still profoundly affect the speculation, emotions and values of the Chinese people and remain our spiritual lifeline. In today's globalization and informatization, facing the impact of multiculturalism such as Western culture and network culture, all kinds of thoughts are repeated, the moral emotions, values and 
spiritual pursuits of college students are faltering, and the environment facing ideological and political education of college students is increasingly Complex, the task is more and more arduous, how to solidify the source, rebuild the ideological foundation and moral foundation of today's college students, and establish cultural self-confidence and value self-confidence.

\section{The countermeasures of college students' ideological and political education under the influence of Chinese traditional culture}

First, play the role of mass media and promote excellent traditional culture. In modern society, the mass media has formed a public opinion environment that has a profound impact on people because of its large amount of information, rapid spread, wide coverage and attractiveness. General Secretary Hu Jintao put forward the important topic of "How to actively and modernly use modern scientific and technological means to enable university students to accept positive and healthy ideology and culture through modern information dissemination channels", and keenly grasp the trend of information development in today's world, and demand us to use modern Media means, firmly grasp the initiative of ideological and political education. The mass media is an effective platform for promoting excellent traditional culture. As far as the school is concerned, it chooses various carriers such as radio, television, newspapers, magazines, etc., and conducts excellent traditional cultural education for college students through easy-to-understand and vivid movies, television, and literature readings. In the context of the development of mass media, the main way to promote traditional culture and understand history is to watch movies and TV dramas. The historical drama that has the character of "history" and the charm of "drama" must bear the heavy responsibility of spreading excellent traditional culture and cultivating national spirit." The school can organize students to watch CCTV's "Hundred Lectures" column; or the school organizes students to watch a certain number of classic film and television dramas reflecting historical themes, such as "Hanwu Emperor” and "Wang Zhaojun Out of the Box” and “ "Long Song", "Long March", "The Founding of the Great" and so on. College students watch film and television dramas that reflect traditional culture or major historical subjects, helping students to establish correct aesthetics and values. At the same time, the school also has plans to organize relevant teachers to guide college students to read the "Four Books and Five Classics" and Chinese classical classics, because "the famous works have perfect explanations for various problems of human existence, including various problems we face in modern life. " In addition, students should be guided to learn related traditional cultural readings, such as Li Zehou's "The Analects of Confucius" and Lin Yutang's "Wisdom of Laozi". College students reading traditional cultural reading materials can not only broaden their knowledge, increase their cultural connotations, but also enrich their spiritual life, cultivate their sentiments and enhance their moral realm.

Second, construct a campus ideological and political education website and promote excellent traditional culture. American futurist Alvin Toffler said: "Whoever has the information and controls the network will have the whole world." The Internet has become a new and important position in the ideological and political education work of colleges and universities. Strengthen the construction of campus network positions and build a unique, influential and influential ideological and political education website (also known as the "red website"). In the campus ideological and political education website, you can open up special excellent traditional culture columns, and conduct extensive discussions and exchanges through the online platform, or guide students to find and download information about traditional culture, or selectively play through the campus network platform. Constructing a campus ideological and political education website combines the essence of Chinese traditional culture through text, images, sounds and animations, breaking the limits of time and space, combining abstract theories with the sensory stimuli of the image, making it boring for fun and making students Being immersed in the situation, students can feel the charm of traditional culture, thus improving the cultural consciousness of college students, and understanding the origin, formation process, internal structure, basic characteristics, value system and development trend of Chinese culture. At the same time, it is necessary to establish a new ideological and political education work team that understands the art of ideological and political 
education, is proficient in traditional culture, and understands information network technology. It guides college students to make full use of red websites or network resources to learn traditional culture and improve the knowledge structure of college students. , constantly improve the humanities quality of college students.

\section{Conclusion}

In order to carry out ideological and political education effectively under the new situation, universities must be rooted in the soil of excellent traditional culture. They must actively explore on the basis of reality, absorb the nutrients of excellent traditional culture, and fully tap the connotation of excellent traditional culture. Let students study and study Chinese traditional culture carefully, influence their emotions through propaganda, education, social practice, etc., stimulate national consciousness and patriotic enthusiasm, establish socialist core values, and open up a new situation of ideological and political education in colleges and universities in the new era.

\section{References}

[1] Guo Ying. The cultural character of the traditional Chinese way of life [J]. Academic Monthly, 2001, (7)

[2] Li Qiang. Chinese people's psychological disorders and traditional culture [J]. People's University copy of the book "Psychology", 2002, (1)

[3] Yan Nana. The Value of Chinese Traditional Culture in College Students' Ideological and Political Education and Its Application [D]. Liaoning Normal University, 2010

[4] Li Zongyun. The value of traditional culture in the ideological and political education of college students and its realization [D]. Northeast Normal University, 2008 